Henis, Y. (1956). J. gen. Microbiol. 15, 462-469

\title{
The Adaptive Formation of Levansucrase by a Species of Corynebacterium
}

\author{
BY Y. HENIS \\ Department of Bacteriology, Hebrew University-Hadassah Medical School, \\ Jerusalem, Israel
}

SUMMARY: Levansucrase in the corynebacterium studied is apparently an adaptive enzyme. Its optinal formation is dependent on the presence of an inducer (sucrose) and an organic nitrogen source. High nitrogen concentrations increase growth rate and sucrose hydrolysis and significantly decrease levansucrase formation. The $\mathbf{p H}$ activity curve of the levansucrase studied is asymmetric and the optimal $\mathrm{pH}$ value for its activity is 7.0. These findings suggest that this levansucrase differs from other levansucrases so far described.

In a preliminary note (Henis \& Aschner, 1954), levan formation by a species of Corynebacterium was described. Maximal yield of levan was obtained in a medium composed of $0.1 \%(w / v) \mathrm{K}_{2} \mathrm{HPO}_{4}$ and $10 \%(\mathrm{w} / \mathrm{v})$ sucrose in tap water. Only unwashed organisms grown on ordinary nutrient agar could serve as inoculum since washed organisms lost most of their levan-synthesizing ability. It was found later that by the addition of small amounts of certain organic nitrogen compounds (peptone, casein hydrolysate, glutamic acid) the levan-synthesizing ability of washed organisms could be regained. The purpose of this work is to evaluate some factors affecting levan formation by the organism studied.

\section{METHODS}

Organism. The organism used was that isolated and described by us as a species of Corynebacterium (Henis \& Aschner, 1954).

Inoculum. The organism was grown for $48 \mathrm{hr}$. at $30^{\circ}$ on a medium composed of $(\%, w / v)$ : glucose, 2 ; peptone, 0.5 ; Marmite, 0.5 ; agar, 2.5 ; in distilled water. The $\mathrm{pH}$ value was adjusted to $7 \cdot 7$ after sterilization. The organisms were washed 3 times with saline, stored in a refrigerator and used during 7 days; their viability did not change during that period. The number of organisms in the inoculum was determined in a Coleman junior spectrophotometer at $550 \mathrm{~m} \mu$., using a calibration curve obtained by the plate count method.

Media. Bacto-peptone ('Difco' standardized) or glutamic acid in concentrations up to $10 \mathrm{mg} . / \mathrm{ml}$. were used as a nitrogen source. The following solutions served as mineral source: (1) boiled and filtered tap water; (2) a solution containing (mg./l.): $\mathrm{MgSO}_{4} .7 \mathrm{H}_{2} \mathrm{O}, 60 ; \mathrm{Na}_{2} \mathrm{CO}_{3}, 200 ; \mathrm{CaCl}_{2}, 4.5 ; \mathrm{Fe}_{2}\left(\mathrm{SO}_{4}\right) 3,0.01$. The buffer used was Sorensen's phosphate buffer ( $\mathrm{pH} 7 \cdot 6$ ). Sucrose, in concentrations up to $100 \mathrm{mg} . / \mathrm{ml}$. served as a substrate for both the levansucrase and the sucrase systems, and as a part of the carbon and energy sources.

Sterilization was at $120^{\circ}$ for $15 \mathrm{~min}$. 
Aeration and continuous suspension of the organisms were obtained by the use of a roller tube (usually used for tissue culture) which rotated $5 \mathrm{rev} . / \mathrm{hr}$. Screw-cap test tubes (19 mm. diam.), each containing $7 \mathrm{ml}$. medium, were put into the rotating instrument in an horizontal position. In this way, the formation of levan gel (Henis \& Ascher, 1954) in the media was avoided.

The incubation temperature in all experiments with growing organisms was $30^{\circ}$.

Growth determinations were carried out with a Coleman junior spectrophotometer at $550 \mathrm{~m} \mu$. by means of a calibration curve against plate count. The turbidity caused by levan formation during growth was eliminated by a mild acid hydrolysis, which did not change the turbidity caused by the growing organisms. Preliminary determinations of levan were made by measuring the turbidity of the levan and the bacteria before and after a mild hydrolysis and subtracting the final turbidity values from the total turbidity. Levan solutions of known concentrations were used as standard solutions.

Determinations of levan and reducing sugar were made by the methods of Somogyi (1945) and Nelson (1944). Levan was prepared for quantitative determination according to the method of Avineri-Shapiro \& Hestrin (1945). All values were expressed as $\mathrm{mg}$. glucose/ml. Glucose solutions of known concentrations were used for standardization purposes.

Determination of protein in cell-free extracts was made by the method of Mehl (1945), with egg albumin solution as a standard.

Preparation of enzyme solutions. Organisms, at a final concentration of $10^{9}$ organisms $/ \mathrm{ml}$., were added to Roux bottles, each containing $100 \mathrm{ml}$. medium ( 10 g. sucrose, $0 \cdot 03 \mathrm{~g}$. peptone, in $\mathrm{M} / 30$ phosphate buffer, $\mathrm{pH} \mathbf{7 \cdot 6}$, in tap water) and incubated for $18 \mathrm{hr}$. at $30^{\circ}$. The organisms, together with part of the levan formed, were then collected in a Sharples supercentrifuge and put in a Raytheon $9 \mathrm{Kc}$ sonic vibrator for $4 \mathrm{~min}$. This treatment decreased the viscosity of the levan and enabled the separation of the organisms, which otherwise precipitated with the levan during centrifugation. The unbroken organisms were collected in a MSE high-speed centrifuge at 10,000 r.p.m. for 10 min., washed 3 times with saline and diluted to $1 / 100$ of the original volume of the medium. The organisms were then put again in the sonic vibrator for $\mathbf{4 0} \mathrm{min}$. and the cell debris separated in the high-speed centrifuge. The cell-free extract contained $3 \mathrm{mg}$. protein $/ \mathrm{ml}$. Protein was precipitated by saturation with ammonium sulphate, and the precipitate dialysed overnight against distilled water and diluted with physiological saline to a final concentration equivalent to $1.5 \mathrm{mg}$. protein $/ \mathrm{ml}$. The extract was free from levan and reducing sugar as judged by the methods used by us. In a similar way, cell-free extracts from organisms grown under various other conditions were prepared.

Composition of reaction mixture and determination of enzymic activity. Reaction mixtures of cell-free extracts contained $0.5 \mathrm{mg} . / \mathrm{ml}$. protein, $50 \mathrm{mg} . / \mathrm{ml}$. sucrose and $\mathrm{m} / \mathbf{4 5}$ phosphate buffer in distilled water. For $\mathrm{pH}$ values higher than $7 \cdot 8 \mathrm{M} / 30 \mathrm{KCl}+$ borate $+\mathrm{NaOH}$ mixtures were used. In all cases, enzymic activity was determined with $3 \mathrm{ml}$. volumes of reaction mixture which were incubated in a $37^{\circ}$ water bath for $2 \mathrm{hr}$. 
Paper chromatography was carried out on Whatman filter-paper no. 1 with n-butanol/acetic acid/water mixture (4: 1:5; Partridge, 1948) as a solvent. Benzidine +trichloroacetic acid (Bacon \& Edelman, 1951) was used as a colour-developing reagent. Ascending chromatograms were run for $48 \mathrm{hr}$. at $30^{\circ}$.

\section{RESULTS}

\section{Experiments with growing organisms}

Effect of nitrogen concentration on levan synthesis. Experiments were carried out in four series; the results are shown in Figs. 1 and 2. The amount of sucrose hydrolysed was calculated by subtracting the glucose values equivalent to the levan formed from the total amount of reducing sugar which appeared in the medium. This calculation was based on the reaction, adapted from Hehre (1955):

$$
n \text { sucrose } \rightarrow \text { levan }+n \text { glucose, }
$$

when all the fructose part of the sucrose is incorporated into levan. No more than $5 \%(w / v)$ of the sucrose was used by the organism as an energy source.

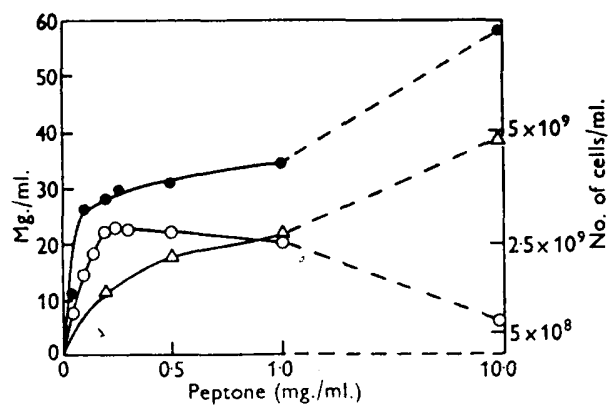

Fig. 1

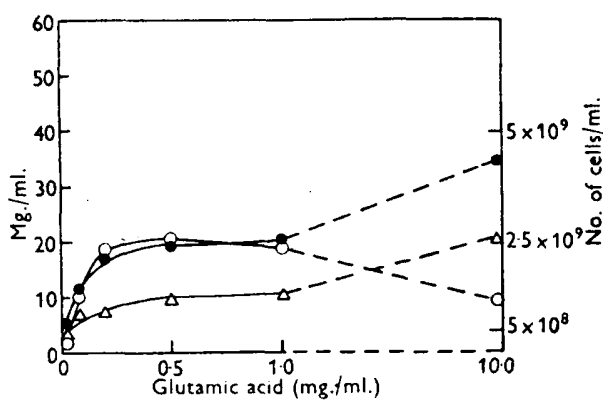

Fig. 2

Fig. 1. Levan production, sucrose hydrolysis and multiplication as a function of peptone concentration. In addition to the nitrogen source, the medium contained $100 \mathrm{mg}$. sucrose $/ \mathrm{ml}$. and $\mathrm{M} / \mathbf{3 0}$ phosphate buffer in tap water. Organisms, at a final concentration of $5 \times 10^{8}$ organisms $/ \mathrm{ml}$., were added to test tubes containing the medium and incubated at $30^{\circ}$ for $18 \mathrm{hr}$. $\mathrm{pH}$ value throughout the experiment: $7 \cdot 5 \pm 0 \cdot 1$. O- $\bigcirc$, levan produced; $\longrightarrow$, sucrose hydrolysed; $\triangle \longrightarrow \triangle$, multiplication.

Fig. 2. Levan production, sucrose hydrolysis and multiplication as a function of glutamic acid concentration. With exception of the nitrogen source, conditions are the same as those described for Fig. 1. $\bigcirc-O$, levan produced; - , sucrose hydrolysed; $\triangle \longrightarrow \triangle$, multiplication.

Similar results were obtained when a defined mineral solution was used instead of tap water (Table 1); when peptone was replaced by glutamic acid, levan formation significantly decreased. This was possibly due to the presence of trace elements in the peptone and thus the tap water medium may be the more correct one for comparing peptone with other nitrogen sources. It may be seen from Figs. 1 and 2 that while sucrose hydrolysis and growth were parallel, levan formation did not follow growth and was depressed at the higher nitrogen concentrations. If the amounts of sucrose hydrolysed and levan formed are calculated/unit weight of organism, it is found that the rate 
of sucrose hydrolysis remains approximately constant, while levan formation is considerably decreased.

Table 1. Levan production, sucrose hydrolysis and multiplication of corynebacterium in the presence of different concentrations of nitrogen

Defined mineral solution served as the mineral source. Sucrose concentration : $100 \mathrm{mg} . / \mathrm{ml}$. Incubation time: $18 \mathrm{hr}$. $\mathrm{pH}$ value throughout the experiment: $7 \cdot 5 \pm 0 \cdot 1$.

\begin{tabular}{|c|c|c|c|c|}
\hline & $\begin{array}{l}\text { Nitrogen } \\
\text { source } \\
\text { (mg./ml.) }\end{array}$ & $\begin{array}{l}\text { Levan } \\
\text { produced } \\
\text { (mg./ml.) }\end{array}$ & $\begin{array}{c}\text { Sucrose } \\
\text { hydrolysed } \\
\text { (mg./ml.) }\end{array}$ & $\begin{array}{l}\text { Multiplication } \\
\text { (organisms/ml.; } \\
\quad \times 5 \times 10^{8} \text { ) }\end{array}$ \\
\hline & None & 1.0 & $2 \cdot 9$ & 1.0 \\
\hline \multirow[t]{4}{*}{ Peptone } & $0 \cdot 2$ & $21 \cdot 0$ & $21 \cdot 9$ & $2 \cdot 8$ \\
\hline & 0.5 & $20 \cdot 1$ & $23 \cdot 1$ & $4 \cdot 0$ \\
\hline & 1.0 & $10 \cdot 8$ & $24 \cdot 0$ & $4 \cdot 9$ \\
\hline & $10 \cdot 0$ & $6 \cdot 1$ & 49.5 & $9 \cdot 0$ \\
\hline \multirow[t]{5}{*}{ Glutamic acid } & 0.1 & $14 \cdot 0$ & $10 \cdot 7$ & $\mathbf{1} \cdot \mathbf{3}$ \\
\hline & 0.2 & $12 \cdot 5$ & $12 \cdot 0$ & $1 \cdot 6$ \\
\hline & 0.5 & $11 \cdot 7$ & $12 \cdot 3$ & $\mathbf{2 \cdot 3}$ \\
\hline & 1.0 & $9 \cdot 8$ & $12 \cdot 5$ & $2 \cdot 7$ \\
\hline & $10 \cdot 0$ & $4 \cdot 2$ & $14 \cdot 8$ & 4.0 \\
\hline
\end{tabular}

Levan synthesis as a function of time. The results of these experiments are shown in Figs. 3 and 4, where it is seen that the inhibition in levan formation in the higher nitrogen concentrations began from the early hours of the experiments.

Effect of various concentrations of sucrose and peptone on levan synthesis. This experiment (Table 2) was carried out to elucidate the importance of the sucrose/peptone ratio on levan formation. It may be concluded that levan synthesis is not affected by that ratio.

Table 2. Levan production, sucrose hydrolysis and multiplication of a corynebacterium in the presence of different concentrations of peptone and sucrose

In additien to peptone and sucrose, the medium contained phosphate buffer $\mathrm{M} / 30, \mathrm{pH} 7 \cdot 6$ in tap water and was inoculated to contain $5 \times 10^{8} \mathrm{organisms} / \mathrm{ml}$. Determinations were made after $18 \mathrm{hr}$. of incubation.

\begin{tabular}{|c|c|c|c|c|c|c|}
\hline \multicolumn{2}{|c|}{$\begin{array}{l}\text { Composition of } \\
\text { the medium }\end{array}$} & \multirow{2}{*}{$\begin{array}{l}\text { Sucrose/ } \\
\text { peptone } \\
\text { ratio }\end{array}$} & \multirow{2}{*}{$\begin{array}{c}\text { Levan } \\
\text { produced } \\
(\mathrm{mg} . / \mathrm{ml} .)\end{array}$} & \multirow{2}{*}{$\begin{array}{l}\text { Amount } \\
\text { of suc. } \\
\text { converted } \\
\text { to levan* } \\
(\%, w / v)\end{array}$} & \multirow{2}{*}{$\begin{array}{c}\text { Sucrose } \\
\text { hydrolysed } \\
\text { (mg./ml.) }\end{array}$} & \multirow{2}{*}{$\begin{array}{l}\text { Multiplication } \\
\text { (organisms/ml. } \\
\quad \times 5 \times 10^{8} \text { ) }\end{array}$} \\
\hline $\begin{array}{l}\text { Sucrose } \\
\text { (mg./ml.) }\end{array}$ & $\begin{array}{l}\text { Peptone } \\
\text { (mg./ml.) }\end{array}$ & & & & & \\
\hline $100 \cdot 0$ & 0.2 & 500 & $22 \cdot 1$ & $22 \cdot 1$ & $27 \cdot 8$ & $3 \cdot 0$ \\
\hline $100 \cdot 0$ & $1 \cdot 0$ & 100 & $20 \cdot 0$ & $20 \cdot 0$ & $33 \cdot 5$ & $5 \cdot 0$ \\
\hline $100 \cdot 0$ & $10 \cdot 0$ & 10 & 6.3 & $6 \cdot 3$ & $58 \cdot 0$ & $9 \cdot 8$ \\
\hline $50 \cdot 0$ & 0.2 & 250 & $10 \cdot 9$ & $21 \cdot 8$ & $14 \cdot 7$ & $2 \cdot 7$ \\
\hline $50 \cdot 0$ & 1.0 & 50 & $11 \cdot 0$ & $22 \cdot 0$ & $20 \cdot 4$ & 4.0 \\
\hline $50 \cdot 0$ & $10 \cdot 0$ & 5 & $\mathbf{3 \cdot 2}$ & 6.4 & $27 \cdot 2$ & $8 \cdot 0$ \\
\hline $10 \cdot 0$ & 0.2 & 50 & $2 \cdot 5$ & $25 \cdot 0$ & $4 \cdot 9$ & $3 \cdot 2$ \\
\hline $10 \cdot 0$ & 1.0 & 10 & $2 \cdot 1$ & $21 \cdot 0$ & $5 \cdot 8$ & 4.7 \\
\hline 10.0 & $10 \cdot 0$ & 1 & 1.0 & 10.0 & $8 \cdot 1$ & $9 \cdot 5$ \\
\hline $5 \cdot 0$ & $0 \cdot 2$ & 25 & 1.0 & $20 \cdot 0$ & $3 \cdot 0$ & $3 \cdot 2$ \\
\hline 5.0 & $1 \cdot 0$ & 5 & 1.0 & $20 \cdot 0$ & $3 \cdot 0$ & $5 \cdot 2$ \\
\hline 5.0 & $10 \cdot 0$ & 0.5 & 0.8 & $17 \cdot 0$ & $3 \cdot 4$ & $10 \cdot 0$ \\
\hline
\end{tabular}

\footnotetext{
* Maximal theoretical yield: $50 \%$.
} 
Experiments with cell-free extracts. Organisms were grown on the media detailed in Table 3 and the cell-free extracts examined for levansucrase and sucrase activities. The results are summarized in Table 3. Sucrase activity of

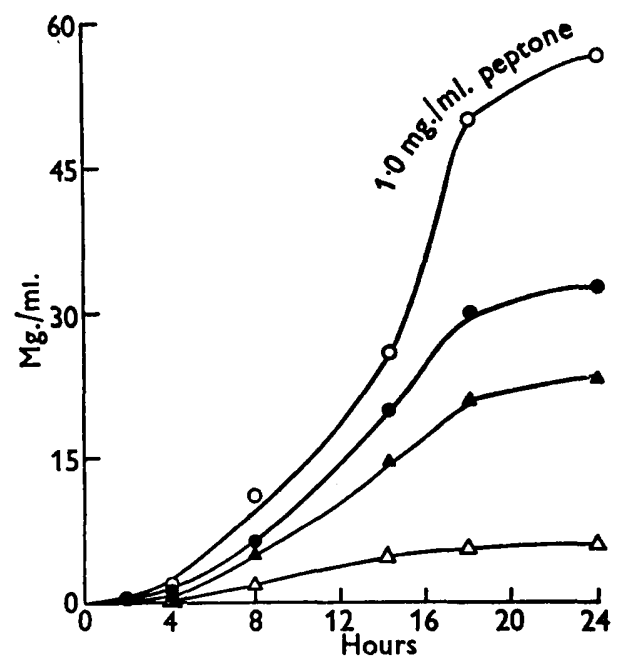

Fig. 3

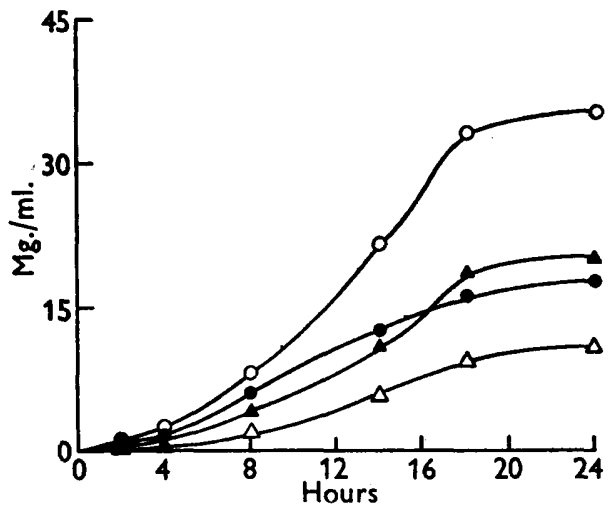

Fig. 4

Fig. 3. Levan production and sucrose hydrolysis as a function of time (nitrogen sourcepeptone). Conditions are the same as those described for Fig. 1. 0.1 ml. were taken at intervals. $\Delta-\Delta$, levan produced in the presence of $0.25 \mathrm{mg}$. peptone $/ \mathrm{ml}$.; $\triangle \longrightarrow \triangle$, levan produced in the presence of $1.0 \mathrm{mg}$. peptone $/ \mathrm{ml}$.; $\longrightarrow$, sucrose hydrolysed in the presence of $0.25 \mathrm{mg}$. peptone/ml.; $\mathrm{O}-\mathrm{O}$, sucrose hydrolysed in the presence of $1.0 \mathrm{mg}$. peptone $/ \mathrm{ml}$.

Fig. 4. Levan production and sucrose hydrolysis as a function of time (nitrogen sourceglutamic acid). With exception of the nitrogen source, conditions are the same as those described for Fig. 1, 0.1 ml. were taken at intervals. $\Delta-\Delta$, levan produced in the presence of $0.25 \mathrm{mg}$. glutamic acid $/ \mathrm{ml}$.; $\triangle \longrightarrow \Delta$, levan produced in the presence of $1.0 \mathrm{mg}$. glutamic acid $/ \mathrm{ml}$.; glutamic acid $/ \mathrm{ml}$; $\mathrm{O}-\mathrm{O}$, sucrose hydrolysed in the presence of $1.0 \mathrm{mg}$. glutamic acid $/ \mathrm{ml}$.

Table 3. Levansucrase and sucrase activity of cell-free extracts obtained from a corynebacterium grown under different conditions

Cell-free extracts were obtained from organisms grown on the following media :(1)A medium composed of phosphate buffer $\mathrm{m} / 30, \mathrm{pH} 7 \cdot 6,0 \cdot 30 \mathrm{mg}$. peptone $/ \mathrm{ml}$. and $100 \mathrm{mg}$. sucrose $/ \mathrm{ml}$. in tap water. (2) The same, with $10 \mathrm{mg}$. peptone $/ \mathrm{ml}$. instead of $0 \cdot 30 \mathrm{mg} . / \mathrm{ml}$. (3) A medium containing $50 \mathrm{mg}$. glucose $/ \mathrm{ml}$. instead of $100 \mathrm{mg}$. sucrose $/ \mathrm{ml}$. (4) As no. 1, without peptone. The reaction mixtures contained $0.5 \mathrm{mg}$. protein $/ \mathrm{ml}$, $50 \mathrm{mg}$. sucrose $/ \mathrm{ml}$. and $\mathrm{M} / 45$ phosphate buffer $\left(\mathrm{pH} \mathrm{7 \cdot 0)}\right.$. They were incubated at $-37^{\circ}$ for $2 \mathrm{hr}$.

Activity of cell-free extracts

\begin{tabular}{|c|c|c|}
\hline $\begin{array}{l}\text { Medium } \\
\text { for } \\
\text { growth }\end{array}$ & $\begin{array}{c}\text { Levan } \\
\text { synthesized } \\
\text { (mg./ml.) }\end{array}$ & $\begin{array}{c}\text { Sucrose } \\
\text { hydrolysed } \\
(\mathrm{mg} . / \mathrm{ml} .)\end{array}$ \\
\hline No. 1 & $5 \cdot 10$ & $9 \cdot 20$ \\
\hline No. 2 & 0.82 & 1.94 \\
\hline No. 3 & 0.054 & 0.042 \\
\hline No. 4 & 0.071 & 0.061 \\
\hline
\end{tabular}


the cell-free extracts was decreased compared with that of the intact organisms grown in the presence of high nitrogen concentration.

Effect of $\mathrm{pH}$ value on levansucrase activity. The results are given in Fig. 5. Optimal activity was obtained at $\mathrm{pH} 7 \cdot 0$; the shape of the $\mathrm{pH}$ activity curve is asymmetric.

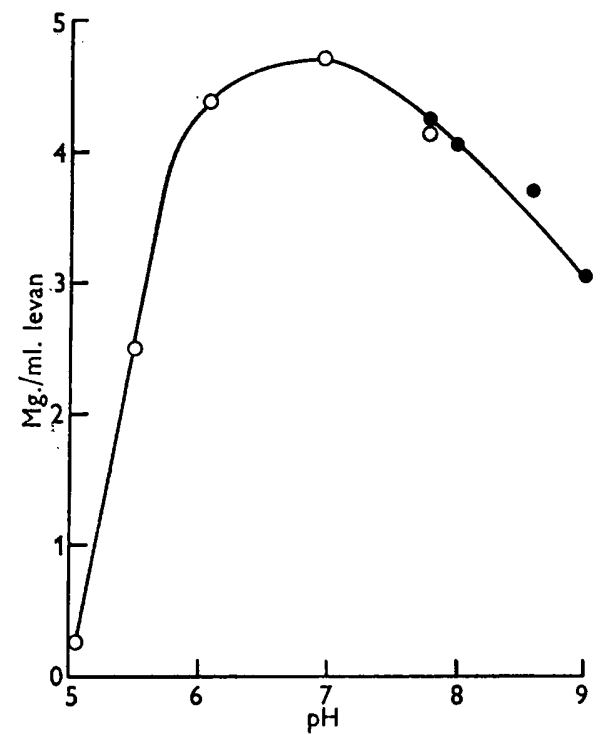

Fig. 5. Effect of $\mathrm{pH}$ on the activity of levansucrase obtained from a Corynebacterium sp. The reaction mixture contained $0.5 \mathrm{mg}$. protein $/ \mathrm{ml}$., $50 \mathrm{mg}$. sucrose $/ \mathrm{ml}$. and phosphate or borate buffer in distilled water. $3 \mathrm{ml}$. of the reaction mixture were incubated at $37^{\circ}$ for $2 \mathrm{hr}$. O-O, Sørensen phosphate buffer $\mathrm{M} / 45$; $\longrightarrow$ KCl-borate-NaOH buffer $\mathbf{M} / \mathbf{3 0}$.

Levan-splitting activity of cell-free extracts. Cell-free extracts were examined for levanase (Hehre, 1955) and levanpolyase (Hestrin \& Goldblum, 1953) activity. Purified levan was incubated with cell-free extracts obtained from organisms grown in low and high concentrations of nitrogen. The reaction mixtures contained $10 \mathrm{mg}$. levan $/ \mathrm{ml}$., $0.5 \mathrm{mg}$. protein $/ \mathrm{ml}$. and $\mathrm{M} / 45$ phosphate buffer $(\mathrm{pH} 7 \cdot 0)$. Reaction mixtures were incubated at $37^{\circ}$. Mixtures of cellfree extracts and levan in buffer were used as controls. In an experiment which lasted for $24 \mathrm{hr}$., four samples were taken at $2 \mathrm{hr}$. intervals and a fifth after $24 \mathrm{hr}$. When examined by paper chromatography, no traces of oligo or monosaccharides could be detected.

\section{DISCUSSION}

The dependence of levansucrase formation on the presence of an inducer (sucrose) and an exogenous nitrogen source (peptone or glutamic acid), leads to the conclusion that this enzyme is adaptive (see review by Karstrom, 1938). An adaptive levansucrase also exists in Bacillus subtilis and in B.polymyxa. The only bacterium known to have a constitutive levansucrase is Aerobacter 
levanicum (Hestrin, Avineri-Shapiro \& Aschner, 1943). Avineri-Shapiro \& Hestrin (1945) described a levansucrase preparation obtained from $A$. levanicum which showed optimal activity in $\mathrm{pH}$ values of $5 \cdot 0-5 \cdot 8$; the shape of the pH activity curve was shown to be symmetric. A similar levansucrase preparation was obtained from $B$. subtilis by Doudoroff \& O'Neal (1945). The levansucrase preparation obtained from the corynebacterium described by us, differs from those preparations in its behaviour towards changes in $\mathbf{p H}$ values (Fig. 5). The decrease of levansucrase formation by the corynebacterium studied here in the presence of a high nitrogen concentration needs further consideration. Similar phenomena were observed by Beijerinck (1912) concerning dextran production by a Leuconostoc sp. and by Duguid \& Wilkinson (1953) when investigating polysaccharide formation by Aerobacter aerogenes. The suggestion by Beijerinck that this phenomenon is due to decrease in the $\mathrm{pH}$ of the medium during growth cannot be accepted here. The suggestion by Duguid \& Wilkinson (1953) that the decrease in polysaccharide formation in $A$. aerogenes is due to the disappearance of the substrate (lactose) as a result of its use by the organisms as an energy source does not meet the present case. Apparently the decrease in polysaccharide formation by the corynebacterium in high nitrogen concentrations is due to the inhibition of enzyme formation. There might also be other factors which inhibit levan formation, such as the presence of glucose in high concentration, which inhibits enzyme action (Hestrin \& AvineriShapiro, 1944). Such a factor cannot be important here as inhibition starts when the amount of reducing sugar is still small and the amounts of reducing sugar both in the presence of low and high nitrogen concentrations are of the same order. Competition might exist between two enzyme-forming systems (levansucrase and sucrase) inside the organisms due to the presence of the common inducer (sucrose). If in higher nitrogen concentrations sucrase is formed before levansucrase and sucrase formation can be induced by lower concentrations of sucrose, then sucrose which penetrated the organism might be hydrolysed before it could induce levansucrase formation. This, however, is not the case, since sucraseactivity/unit wt. of organism remained approximately constant both in low and high concentrations of nitrogen. A working hypothesis to explain this phenomenon involves the possible interconversion between levansucrase and sucrase or other enzyme system. In testing this hypothesis, certain difficulties are unavoidable. It is uncertain how much sucrose is hydrolysed by levansucrase itself since preparations of this enzyme from other bacteria are known to hydrolyse sucrose (Hehre, 1955). Another difficulty is our failure to prepare enzyme solutions, from organisms grown in high nitrogen concentration, which will show the same relation between sucrase and levansucrase activities as do the growing organisms. Short-period experiments with resting organisms might be helpful in trying to solve this problem.

I wish to express my gratitude to Professor M. Aschner under whose direction this work was performed, for his generous advice. I should also like to thank Miss Dinah Godinger for technical assistance. 


\section{REFERENCES}

Avineri-Shapiro, S. \& Hestring. S. (1945). The mechanism of polysaccharide formation from sucrose, 2. Biochem. J. 39, 167.

Bacon, J. S. D. \& Edelman, J. (1951). The carbohydrates of the Jerusalem Artichoke and other Compositae. Biochem. J. 48, 114.

Beijerinck, M. W. (1912). Die durch Bakterien aus Rohzucker erzeugten schleimigen Wanstoffe. Folia microbiol., Delft. 1, 377.

Doudoroff, M. \& O'Neal, R. (1945). The reversibility of Levulan synthesis by Bacillus subtilis. J. biol. Chem. 159, 585.

Duguid, J. P. \& Wilkinson, J. F. (1953). The influence of cultural conditions on polysaccharide production by Aerobacter aerogenes. J. gen. Microbiol. 9, 174.

HeHre, E. J. (1955). In Methods in Enzymology. Ed.: Colowick, S. P. \& Kaplan, N. O. New York: Academic Press.

Henis, Y. \& Aschner, M. (1954). Levan formation in a species of Corymebacterium. Bull. Res. Coun. Israel, 4, 209.

Hestrin, S. \& Avineri-Shapiro, S. (1944). The mechanism of polysaccharide formation from sucrose. Biochem. J. 38, 2.

Hestrin, S., Avineri-Shapiro, S. \& Aschner, M. (1943). The enzymic production of levan. Biochem. J. 37, 450.

Hestrin, S. \& Goldblum, J. (1953). Levanpolyase. Nature, Lond. 172, 1046.

Karstrom, H. (1938). Enzymatische Adaptation bei Mikroorganismen, in: Ergebnisse der Enzymforschung, 7, 350. Leipzig: Akademischer Verlag.

MeHL, J. W. (1945). The biuret reaction of proteins in the presence of ethylene glycol. J. biol. Chem. 157, 173.

Nelson, N. (1944). A photometric adaptation of the Somogyi method for the determination of glucose. J. biol. Chem. 153, 375.

Partridge, S. M. (1948). Filter paper partition chromatography of sugars. Biochem. J. 42, 238.

Somogyi, M. (1945). A new reagent for the determination of sugars. J. biol. Chem. $160,61$.

(Received 25 April 1956) 